\title{
THE INTERNATIONAL RESPONSIBILITIES OF DEVELOPED COUNTRIES IN ADAPTATION TO AND MITIGATION OF CLIMATE CHANGE: \\ AN ETHICAL MANDATE
}

\author{
MEGERSA DUGASA FITE, \\ School of Law, Ambo University (Ambo, Ethiopia)
}

DOI: $10.21684 / 2412-2343-2018-5-2-100-111$

This article asserts three propositions. First, climate change and/or global warming has (and will continue to have) qualitative differences in its nature and impact on rich and poor countries, thus demonstrating the imperative of adaptation to and mitigation of its effects. Second, the current international environmental regime is insufficient for sensible global distributive justice. What is more, in the absence of an adequate regime the world continues to ignore fundamental ethical issues and the immediate needs of climate-vulnerable countries. Third, the effective preservation of the environment necessitates that developed countries bear the (ethical) responsibility for meeting the costs associated with climate change, and urgently and unremittingly discharge their obligation to assist developing and/or least developed countries in adapting to and mitigating the impact of global warming.

Keywords: climate change/global warming; adaptation and mitigation; international environmental regime; ethical responsibility.

Recommended citation: Megersa Dugasa Fite, The International Responsibilities of Developed Countries in Adaptation to and Mitigation of Climate Change: An Ethical Mandate, 5(2) BRICS Law Journal 100-111 (2018).

\section{Table of Contents}

Introduction

1. Adaptation to and Mitigation of Climate Change: An Ethical Mandate

2. Who Should Pay the Costs of Climate Change? 


\section{What Form Should the Obligations Take?}

\subsection{Problems with the Current International Environmental Regime}

3.2. What Further Obligations Do Developed Countries Have to Assist (Developing/Least Developed Countries) in Adapting to and Mitigating Climate Change?

3.2.1. Adaptation

3.2.2. Mitigation

\section{Conclusion}

\section{Introduction}

The science is clear regarding the fact of climate change (namely, any change in climate over time, whether due to natural variability or as the result of human activity). Observations show that the global climate system is warming decisively because of human activity that is causing average global temperatures to rise, a phenomenon commonly called "global warming." One resulting effect is seen in features of extreme weather conditions including drought, heavy precipitation, heat waves and the increased intensity of tropical cyclones. Experimental evidence suggests that greenhouse gas (GHG) emissions at or above current rates will cause greater warming and bring about many changes in the global climate system during the $21^{\text {st }}$ century, and, therefore, "tipping points" may occur sooner and at lower GHG concentrations than previously expected unless emissions are cut drastically and promptly.

\section{Adaptation to and Mitigation of Climate Change: An Ethical Mandate}

Founded on this imminent climate disaster, the Intergovernmental Panel on Climate Change (IPCC) definitively concluded that, "[Adaptive] capacity needs to be improved everywhere." For the purposes of our discussion, adaptation should be considered alongside mitigation. In addition, adaptation should be understood as practical steps to protect developing and/or least developed countries (LDCs) from the likely harm that will result from the impact of global warming ${ }^{2}$ and mitigation as policies concomitant with the limitation and/or reduction of GHG emissions ${ }^{3}$ significantly more in developed countries.

\footnotetext{
Martin Parry et al. Technical Summary in Climate Change 2007: Impacts, Adaptation and Vulnerability: Contribution of Working Group II to the Fourth Assessment Report of the Intergovernmental Panel on Climate Change 23, 43 (M. Parry et al. (eds.), Cambridge: Cambridge University Press, 2007).

2 Ellina Levina \&Dennis Tirpak, Adaptation to Climate Change:Key Terms, OECD, COM/ENV/EPOC/IEA/SLT(2006)1 (May 2006), at 6 (Jun. 12, 2018), available at http://www.oecd.org/dataoecd/36/53/36736773.pdf.

3 Id. at 9 , note 8 .
} 
Broadly, there are three reasons why adaptation is an ethical issue. To begin with, there are the concerns as to what we should value and why. There are also the issues of who is responsible for meeting the costs of adaptation and who is eligible for adaptation assistance, issues both of which have ethical magnitudes. ${ }^{4}$ Lastly, adaptation is a governance issue, because it involves action or inaction on the part of both individuals and political actors. ${ }^{5}$ These truths are further strengthened by five specific facts.

First and foremost, because it is both spatially and temporally diffuse in cause and effect, climate change involves exceptionally multi-dimensional, intra- and intergenerational ethical challenges. ${ }^{6}$ Though it will impact on most of humanity, climate change and/or global warming presents a division both in terms of culpability and in terms of vulnerability. ' Largely, shocking impacts will be felt by the world's most vulnerable communities in the global south that do not have the capabilities of adaptation, communities located, for example, in drought-prone parts of Africa, areas of Asia susceptible to flooding and parts of the Caribbean and the Pacific coastline exposed to hurricanes and storms. ${ }^{8}$ What is more, the present theoretical tools are ineffectual in addressing the basic issues involved in climate change, such as intergenerational equity, animal life, nature and more, presenting substantial obstacles to efforts aimed at implementing a fruitful solution to the problem. ${ }^{9}$ Given the very complex issues it involves, adaptation in particular may pose a great difficulty to finding an appropriate reaction. ${ }^{10}$

Secondly, the language (of justice) itself is appealed." Since important human, environmental and inter-generational good in general are threatened by climate change, meeting the costs of adaptation is a requisite of justice despite the reality

4 Lauren Hartzell-Nichols, Responsibility for Meeting the Costs of Adaptation, 2(5) WIREs Climate Change 687,690 (2011).

5 W. Neil Adger et al., Adaptation Now in Adapting to Climate Change: Thresholds, Values, Governance 1 (W.N. Adger et al. (eds.), Cambridge: Cambridge University Press, 2009).

6 Stephen M. Gardiner, The Perfect Moral Storm: The Ethical Tragedy of Climate Change 489 (Oxford: Oxford University Press, 2011), as cited in Hartzell-Nichols 2011, at 690, note 20. See also Stephen M. Gardiner, A Perfect Moral Storm: Climate Change, Intergenerational Ethics and the Problem of Moral Corruption, 15 Environmental Values 397, 397 (2006).

7 UNFCCC, Climate Change: Impacts, Vulnerabilities and Adaptation in Developing Countries (2007), at 26-29 (Jun. 12, 2018), available at http://unfccc.int/resource/docs/publications/impacts.pdf. See also Dan Kuwali, From the West to the Rest: Climate Change as a Challenge to Human Security in Africa, 17(3) African Security Review 18, 25 (2008).

8 Kuwali 2008, at 25. See also Ashleigh Downing \& Alain Cuerrier, A Synthesis of the Impacts of Climate Change on the First Nations and Inuit of Canada, 10(1) Indian Journal of Traditional Knowledge 57, 57-58 (2011); Anthony Costello et al., Managing the Health Effects of Climate Change, 373 Lancet 1693, 1694 (2009).

9 Gardiner 2006, at 407.

10 Hartzell-Nichols 2011, at 691.

11 Id. 
of scientific and policy ambiguity. ${ }^{12}$ Thirdly, because they are variable, the reasons provided in answer to the question "Why is adaptation necessary?"133 basically connote the ethical nature of adaptation, as there are many different ways of understanding the morally related harms. ${ }^{14}$

The theoretical and practical links adaptation has with broader development goals is the fourth fact. Improving health services through decreasing the threat of increased tropical diseases due to warming, for instance, can be a common goal of development and adaptation. ${ }^{15} \mathrm{~A}$ shortcoming, though, is that such an approach of integration may make it even more difficult to assign responsibility for meeting the costs of climate change. ${ }^{16}$

The fifth and equally significant fact is that other domains of the world may be harmfully affected by climate change, and hence questions about the ethical standing of other species and nature are central. ${ }^{17}$ Considering the anthropocentric focus of all of the above approaches, even when the integrity of the ecosystem is at risk, this argument merits consideration. Nonetheless, it is still a challenge, given the difficulty of concurrently protecting human beings and the world of nature permanently. ${ }^{18}$

Overall, these clusters of arguments suggest why adaptation necessarily is an ethical issue and/or imperative.

\section{Who Should Pay the Costs of Climate Change?}

There is an enduring theoretical disagreement as to which nations have the responsibility to meet the costs of adaptation, as neither history nor philosophy

12 Darrel Moellendorf, Justice and the Assignment of the Intergenerational Costs of Climate Change, 40(2) Journal of Social Philosophy 204, 205 (2009). See also Stephen N. Schneider \& Janica Lane, Dangers and Thresholds in Climate Change and the Implications for Justice in Fairness in Adaptation to Climate Change 23 (W.N. Adger et al. (eds.), Cambridge: MIT Press, 2006) as cited in Hartzell-Nichols 2011, at 691, note 15; The Time for Ecological Justice Is Now, Ecological Justice, Backgrounder 2011-2016 (Jun. 12, 2018), available at https://www.devp.org/sites/www.devp.org/files/documents/materials/ devpeace_backgrounder_2011-2016_ecological_justice.pdf.

13 Simon Caney, Climate Change, Human Rights and Moral Thresholds in Human Rights and Climate Change 69 (S. Humphreys (ed.), Cambridge: Cambridge University Press, 2010) as cited in HartzellNichols 2011, at 691, note 38.

14 Hartzell-Nichols 2011, at 691.

15 Id. at 691-692. See also Stephen R. Dovers \& Adnan A. Hezri, Institutions and Policy Processes: The Means to the Ends of Adaptation, 1(2) WIREs Climate Change 212, 227 (2010).

16 Hartzell-Nichols 2011, at 692.

17 Id. See also Dennis Patrick O'Hara \& Alan Abelsohn, Ethical Response to Climate Change, 16(1) Ethics and the Environment 25 (2011); Adger et al. 2009; Environmental Ethics: Readings in Theory and Application 678 (L.P. Pojman (ed.), $4^{\text {th }}$ ed., Toronto: Wadsworth Thomson, 2005) as cited in Hartzell-Nichols 2011, at 692 , note 42 .

18 Hartzell-Nichols 2011, at 692. 
offers a conclusive guide to what would constitute a fair distribution of burden. ${ }^{19}$ Reasonably, however, three common correlated arguments can be put forward to attribute this responsibility to the developed nations.

The principal one is the overwhelming historical and current responsibility of these countries for most of the GHG in the earth's atmosphere..$^{20}$ This argument addresses the disconnection between responsibility for cause and effect. ${ }^{21}$ Because climate science suggests that anthropogenic emissions destabilise some of the earth's natural systems ${ }_{1}^{22}$ the current dangerous climate events - including global warming - are the result of the last two centuries of industrialisation and widespread mercantile capitalist production in the North. Nevertheless, this approach is deficient because, among other things, it stresses historical responsibility rather than offering prompt solutions in general..$^{23}$

The wealth accumulated by the developed countries from unconstrained fossilfuel industrialisation and the consequent ability to provide the funds for adaptation are the foundations for the other two arguments..$^{24}$ Together, they form an approach that concentrates on those who are guilty of free-riding on the welfare created by the underlying activities that are the causes of climate change. ${ }^{25}$ Given that it does not depend on historical blame, but on who benefitted, this sort of approach does seem to offer a better solution. Nevertheless, it is still problematic, since it frequently combines the arguments about capacity, responsibility and impact whereas in theory they are separate. ${ }^{26}$

Critics further emphasise two considerable flaws in the above approaches. Primarily, the arguments largely isolate from the discourse the principal issue of how

19 Marina Cazorla \& Michael Toman, International Equity and Climate Change Policy, Climate Issue Brief No. 27, Resources for the Future (December 2000), at 1 (Jun. 12, 2018), available at http://www.rff. org/files/sharepoint/Worklmages/Download/RFF-CCIB-27.pdf.

20 Jeremy Moss, Climate Justice in Climate Change and Social Justice 51, 53-54 (J. Moss (ed.), Carlton, Vic.: Melbourne University Press, 2009). See also Paul G. Harris, World Ethics and Climate Change: From International to Global Justice 121 (Edinburgh: Edinburgh University Press, 2010); Cass R. Sunstein, Irreversible and Catastrophic: Global Warming, Terrorism, and Other Problems Eleventh Annual Lloyd K. Garrison Lecture on Environmental Law, 23(1) Pace Environmental Law Review 3 (2005).

21 Henry Shue, Global Environment and International Inequality, 75(3) International Affairs 531, 534 (1999).

22 Climate Change: Impacts, Vulnerabilities and Adaptation in Developing Countries, supra note 7, at 2. See also Climate Change 2007: Synthesis Report: Summary for Policymakers (2007) (Jun. 12, 2018), available at http://www.ipcc.ch/pdf/assessment-report/ar4/syr/ar4_syr_spm.pdf.

23 Moss 2009, at 54-55.

24 Id. at 55 . See also Shue 1999, at 7.

25 Moss 2009, at 56. See also Axel Gosseries, Historical Emissions and Free-Riding, 11(1) Ethical Perspectives 36 (2004).

26 Moss 2009, at 57-58. 
the global South has been dispossessed of the capacity and/or resources needed to self-reliantly respond to the catastrophe that it is the first to suffer from and the worst presently affected..$^{27}$ The history of colonialism (the formal relation, the political domination and the economic exploitation), and a history of "coloniality" against humanity and nature as epistemicide and ecocide, respectively, ${ }^{28}$ is the biggest impediment to climate justice today, because it helps to identify the roots of injustice as an epistemological crisis of coloniality ${ }^{29}$ and it results in intra-generational (underdevelopment in the global South) and inter-generational (unsustainable economic activities) injustices. ${ }^{30}$ The mentioned arguments, however, fail to openly address this element of historical restraint.

The second flaw is that the arguments are preoccupied with the North-South (intra-generational) aspects of climate justice, ignoring inter-generational concerns. ${ }^{31}$ Although it is theoretically extremely complex and hard to operationalise, intergenerational equity must be underlined, as it is a key component of any sustainability worldview and because it favours mitigation efforts which ultimately reduce the risk of "runaway" climate change. ${ }^{32}$

Therefore, founded on the aggregate accounts explored above, this essay maintains the view that developed countries should bear the greatest (ethical) responsibility for meeting the costs of adaptation.

\section{What Form Should the Obligations Take?}

The U.N. Framework Convention on Climate Change (UNFCCC) states that,

Parties should protect the climate system... on the basis of equity and in accordance with their common but differentiated responsibilities and respective capabilities. ${ }^{33}$

27 Sam Adelman, Re-Imagining Climate Justice in the Ecology of Knowledges, a draft of a chapter in Re-Imagining Our Sociological Contemporaneity: What Is the Age of Re-Embodiments? (forthcoming from Greenhouse Press), at 7.

28 Id.

29 Anibal Quijano, Coloniality of Power, Eurocentrism, and Latin America, 1(3) Nepantla: Views from the South 533, 533-553 (2000).

30 Adelman, Re-Imagining, supra note 27 , at 7-8.

31 Jeremy Baskin, The Impossible Necessity of Climate Justice?, 10(2) Melbourne Journal of International Law 424, 426 (2009).

32 Id. at 426 , note 10 .

33 United Nations Framework Convention on Climate Change, 9 May 1992, Art. 3 (Jun. 12, 2018), available at http://unfccc.int/resource/docs/convkp/conveng.pdf. 
Accordingly, a classification of rich countries (Annex I UNFCCC) with obligations to reduce their emissions and poor and medium-income countries (non-Annex I UNFCCC) without this obligation was established..$^{34}$ In addition, developed nations are responsible for funding climate change initiatives around the globe by providing, among other things, "new and additional financial resources" for LDCs. ${ }^{35}$ Furthermore, the Kyoto Protocol to the UNFCCC went into effect in 2005 as the first instrument with legally binding emission reduction targets and timetables. ${ }^{36}$

\subsection{Problems with the Current International Environmental Regime}

Essentially, the current international environmental regime performs well in terms of recognising and including theories and rules for distributive justice between rich countries and poor countries. ${ }^{37}$ However, the existing framework response towards the problem of climate justice is criticised for its manifold weaknesses. Primarily, it is equivocal on the details of how climate justice might be addressed. ${ }^{38}$ Also, emission reductions alone cannot be an adequate solution to "(dangerous) climate change" in that even if Annex I countries reduced their emissions to nil and other countries took modest action, the vulnerability would still persist. ${ }^{39}$ Worse, there are now very limited carbon funds in the international market, which shows that developed countries cannot even meet their Kyoto Protocol obligations. ${ }^{40}$ Additionally, there is the pragmatic problem that the extensive economic growth that began in the early 1990s has hardly been environmentally sustainable. ${ }^{41}$ Lastly, critics point out that

34 Art. 4(2) of the United Nations Framework Convention on Climate Change.

35 Id. Arts. 4(9), 4(1)(e), and 3(5).

36 Kyoto Protocol to the United Nations Framework Convention on Climate Change, 10 December 1997 (Jun. 12, 2018), available at https://unfccc.int/resource/docs/convkp/kpeng.pdf. See also Warwick J. McKibbin \& Peter J. Wilcoxen, Climate Change Policy After Kyoto: Blueprint for a Realistic Approach 43 (Washington: Brookings Institution Press, 2002) as cited in Addie Haughey, The World Bank Clean Technology Fund: Friend or Foe to the UNFCCC?, 9(2) Sustainable Development Law \& Policy 57, 61 (2009).

37 Chukwumerije Okereke, Climate Justice and the International Regime, 1(3) WIREs Climate Change 462, 471 (2010).

38 Baskin 2009, at 426. See also Roda Verheyen \& Peter Roderick, Beyond Adaptation: The Legal Duty to Pay Compensation for Climate Change Damage, WWF-UK Climate Change Programme Discussion Paper (November 2008), at 10-13 (Jun. 12, 2018), available at http://assets.wwf.org.uk/downloads/ beyond_adaptation_lowres.pdf.

39 Baskin 2009, at 426-427. See also Charles H. Greene et al., A Very Inconvenient Truth, 23(1) Oceanography 214, 214 (2010).

40 Charlotte Streck \& Jolene Lin, Making Markets Work: A Review of CDM Performance and the Need for Reform, 19(2) European Journal of International Law 409, 420 (2008). See also Christopher Carr \& Flavia Rosembuj, Flexible Mechanisms for Climate Change Compliance: Emission Offset Purchases Under the Clean Development Mechanism, 16 New York University Environmental Law Journal 43, 50 (2008).

41 Baskin 2009, at 427. 
the present regime has not provided a foundation able to sufficiently overturn the underlying forces and permanent structures of global inequality. ${ }^{42}$

The control of global ecological change and its challenges, such as global warming, in the international governance arena continues approximately on the basis of the prevailing notion of market-based conceptions of distributive equity. ${ }^{43}$ The outcome is that fundamental concepts of climate justice remain excluded in the administration of development circles. ${ }^{44}$

\subsection{What Further Obligations Do Developed Countries Have to Assist (Develo- ping/Least Developed Countries) in Adapting to and Mitigating Climate Change?}

Despite existing legal and factual gaps, and given the risk that climate change will become excessively expensive for adaptation, ${ }^{45}$ developed countries should undertake the following key obligations to assist developing countries and/or LDCs in adapting to and mitigating global warming. The analysis here is made separately for adaptation and mitigation and, in addition to UNFCCC, is mainly founded on a clear understanding of the relevant ethical principles and/or renewed appreciation of the inter-relationships between humanity and the environment as revealed above.

\subsubsection{Adaptation}

In respect of adaptation, numerous official and familiar promises, such as lump sum monetary transfers, insurance plans or technology transfers, have been made to help increase the adaptive capacity of the climate-vulnerable in the developing countries and LDCs. ${ }^{46}$ However, contemporaneous evaluations show that most of the promises have not been executed adequately and/or have even collapsed. For instance, up to the present time the G8 countries have delivered very limited funding to adaptation efforts in developing countries, a meagre amount which indeed does

42 Okereke 2010, at 471.

43 Id.

44 Id.

45 Martin Parry et al., Assessing the Costs of Adaptation to Climate Change: A Review of the UNFCCC and Other Recent Estimates (London: International Institute for Environment and Development and Grantham Institute for Climate Change, 2009). See also Adapting to Climate Change: What's Needed in Poor Countries, And Who Should Pay, Oxfam Briefing Paper 104 (2007) (Jun. 12, 2018), available at https://policy-practice.oxfam.org.uk/publications/adapting-to-climate-change-whats-neededin-poor-countries-and-who-should-pay-114075; Sven Harmeling \& Kit Vaughan, Climate Change Adaptation in Developing Countries: What the G8 Has to Deliver, WWF-UK Discussion Paper (July 2008), at 1-2 (Jun. 12, 2018), available at http://germanwatch.org/klima/g8adapt08.pdf.

46 UNFCCC, Report of the Conference of the Parties on Its Seventh Session, Held at Marrakesh from 29 October to 10 November 2001, Addendum - Part Two: Action Taken by the Conference of the Parties, $7^{\text {th }}$ Sess., U.N. Doc FCCC/CP/2001/13/Add.1, 21 January 2002 (Decision 7/CP.7 - funding under the Convention) (Jun. 12, 2018), available at http://unfccc.int/resource/docs/cop7/13a01.pdf. See also Verheyen \& Roderick, supra note 38, at 27-28. 
not meet even the most urgent adaptation needs. The G8 countries also proclaimed their willingness to support climate research and risk assessments, but without any joint guarantees to distribute the available funds. ${ }^{47}$ Mainly what is expected of the developed countries pertaining to adaptation then is that they must implement the many monetary and other various aid proposals, and promptly and without interruption deliver the tens of billions of dollars promised and/or needed to prepare the vulnerable and poor countries for adaptation efforts. ${ }^{48}$ Further allied key (and real) assistance, though this list is incomplete (and already familiar), might include:

- improving the scientific capabilities and research capacity of the climatevulnerable;

- pursuing research and development into mitigation and adaptation technologies that would help humanity sustainably meet its future energy and other natural resource needs, and help cope with harms that climate change will exacerbate;

- reinforcing and, wherever applicable, developing institutes that, in a timely manner, collect, screen and publicise dynamic information on climate, climate change and/or global warming and its impact for decision makers and/or communities at all levels;

- reducing unnecessary subsidies, in particular, grants for food and agriculture which can lead to mal-adaptation; for instance, overuse of marginal lands, chemical inputs and water;

- empowering these countries and their local communities. This is most crucial, because it increases adaptability by increasing community responsibilities and awareness of changes. ${ }^{49}$ Science is worthy but science and traditional knowledge together are superior in efforts to tackle global warming..$^{50}$ While transparency of benchmarks, distribution and monitoring can and should be demanded ${ }^{51}$ the developing countries and/or LDCs pursuing assistance must ultimately decide the collection and combination of adaptive policies tailored in respect of their own indigenous knowledge. Inter alia community-based adaptation ${ }^{52}-$ i.e. initiatives aimed at serving the communities most at risk to promote schemes, and with the money going directly to them rather than dripping down through (global and) national financial channels - will be vital. ${ }^{53}$

47 Harmeling \& Vaughan, supra note 45, at 1-4. See also Maxine Burkett, Climate Reparations, 10(2) Melbourne Journal of International Law 509, 532 (2009).

48

49

50

51 Harmeling \& Vaughan, supra note 45 , at 4.

52 Lisa Friedman, Bangladesh Needs the West's Help, But Isn't Waiting for It, ClimateWire (US), 30 March 2009 (Jun. 12, 2018), available at http://www.nytimes.com/cwire/2009/03/30/30climatewire-bangladeshneeds-the-wests-help-but-isnt-wai-10340.html?pagewanted=all.

53 Burkett 2009, at 533. 


\subsubsection{Mitigation}

Adaptation, however exhaustive, will truly be meaningless if combative mitigation is not achieved globally and significantly more in the developed countries. ${ }^{54}$ Hence, with regard to mitigation two key obligations are actively sought from the industrialised nations. Chiefly, they must implement the 2020 reduction targets consistent with the $2^{\circ} \mathrm{C} \mathrm{limit} .^{55}$ The present policies in the developed world aimed at pursuing construction of coal-fired power plants without $\mathrm{CO} 2$ capture prove that they do not yet appreciate the gravity of the risks associated with global warming ${ }^{56}$ Notably, in the USA there is no meaningful policy modification towards confronting the extreme harm of global warming to which we have subjected billions of people of our present and future generations. ${ }^{57}$ Global warming is progressively expected to reach levels that will be catastrophic particularly for developing countries and/or LDCs if the G8 and other developed countries do not immediately start to reduce their GHG emissions so as to at least keep the warming at or below the $2^{\circ} \mathrm{C}$ target. ${ }^{58}$ Even a $2^{\circ} \mathrm{C}$ temperature increase stabilisation will lead to severe impact ${ }^{59}$ and, upsettingly, emissions from emerging economies are also increasing, thus requiring action no matter how unfair it may seem. ${ }^{60}$ But developed countries still have the greatest responsibility to substantially lower their carbon footprint notwithstanding the political and/or sovereignty arguments that claim the impracticability of such a duty, ${ }_{1}^{61}$ given the consequences for the most vulnerable, indeed for all of humanity, ${ }^{62}$ for sovereignty will never deliver global justice. ${ }^{63}$ Therefore, given the uncertainty and yet the clearly grave risks associated with climate change, developed countries must collectively commit at least to the 2020 targets so as to keep global warming at or below $2^{\circ} \mathrm{C} .{ }^{64}$

Moreover, mitigation efforts require a guarantee of non-repetition from the developed countries in the form of, among other steps, serious measures of shifts

\footnotetext{
54 Burkett 2009, at 533.

55 Harmeling \& Vaughan, supra note 45 , at 2.

56 James Hansen et al., Target Atmospheric CO2: Where Should Humanity Aim?, 2 Open Atmosphere Science Journal 217, 229 (2008).

57 Burkett 2009, at 534.

58 Harmeling \& Vaughan, supra note 45 , at 2.

59 Id.

${ }^{60}$ Id. See also Sam Adelman, Between the Scylla of Sovereignty and the Charybdis of Human Rights: The Pitfalls of Development in Pursuit of Justice, 2(1) Human Rights and International Legal Discourse 17, 19 (2008).

61 Hansen et al. 2008, at 226-227.

62 Burkett 2009, at 534.

63 Adelman 2008, at 35.

64 Harmeling \& Vaughan, supra note 45, at 2.
} 
in policy that secure non-repetition and the raising of public - not to mention their own - awareness. ${ }^{65}$

\section{Conclusion}

A unilateral solution to climate change which does not involve general geoengineering cannot be attained (even imagined), and hence we will need to become involved with climate justice more deeply than we have up to now. An ethical solution is evidently imperative in order to tackle global warming universally and lay a foundation for a more equitable global order which is able to operate within a finite environment. This imposes a variety of obligations on the developed countries. They must (among other measures) take immediate and exigent action now to fulfill their existing (as well as agree and implement future) financial assistance and other commitments, so as to meet the costs of climate change and/or adaptation efforts in those most vulnerable countries. Furthermore, they must be determined in their efforts related to short- and long-term mitigation or achieving emission reduction targets in order to keep global warming (at or below) the $2^{\circ} \mathrm{C}$ limit.

\section{References}

Adelman S. Between the Scylla of Sovereignty and the Charybdis of Human Rights: The Pitfalls of Development in Pursuit of Justice, 2(1) Human Rights and International Legal Discourse 17 (2008).

Adger W.N. et al. Adaptation Now in Adapting to Climate Change: Thresholds, Values, Governance 1 (W.N. Adger et al. (eds.), Cambridge: Cambridge University Press, 2009).

Baskin J. The Impossible Necessity of Climate Justice?, 10(2) Melbourne Journal of International Law 424 (2009).

Burkett M. Climate Reparations, 10(2) Melbourne Journal of International Law 509 (2009).

Caney S. Climate Change, Human Rights and Moral Thresholds in Human Rights and Climate Change 69 (S. Humphreys (ed.), Cambridge: Cambridge University Press, 2010).

Carr C. \& Rosembuj F. Flexible Mechanisms for Climate Change Compliance: Emission Offset Purchases Under the Clean Development Mechanism, 16 New York University Environmental Law Journal 43 (2008).

Cazorla M. \& Toman M. International Equity and Climate Change Policy, Climate Issue Brief No. 27, Resources for the Future (December 2000) (Jun. 12, 2018), available at http://www.rff.org/files/sharepoint/Worklmages/Download/RFF-CCIB-27.pdf.

Downing A. \& Cuerrier A. A Synthesis of the Impacts of Climate Change on the First Nations and Inuit of Canada, 10(1) Indian Journal of Traditional Knowledge 57 (2011).

65 Burkett 2009, at 534. 
Environmental Ethics: Readings in Theory and Application (L.P. Pojman (ed.), $4^{\text {th }}$ ed., Toronto: Wadsworth Thomson, 2005).

Gardiner S.M. A Perfect Moral Storm: Climate Change, Intergenerational Ethics and the Problem of Moral Corruption, 15 Environmental Values 397 (2006).

Gardiner S.M. The Perfect Moral Storm: The Ethical Tragedy of Climate Change (Oxford: Oxford University Press, 2011).

Gosseries A. Historical Emissions and Free-Riding, 11(1) Ethical Perspectives 36 (2004).

Greene C. et al. A Very Inconvenient Truth, 23(1) Oceanography 214 (2010).

Hansen J. et al. Target Atmospheric CO2: Where Should Humanity Aim?, 2 Open Atmosphere Science Journal 217 (2008).

Harris P.G. World Ethics and Climate Change: From International to Global Justice (Edinburgh: Edinburgh University Press, 2010).

Haughey A. The World Bank Clean Technology Fund: Friend or Foe to the UNFCCC?, 9(2) Sustainable Development Law \& Policy 57 (2009).

Kuwali D. From the West to the Rest: Climate Change as a Challenge to Human Security in Africa, 17(3) African Security Review 18 (2008).

Moellendorf D. Justice and the Assignment of the Intergenerational Costs of Climate Change, 40(2) Journal of Social Philosophy 204 (2009).

Moss J. Climate Justice in Climate Change and Social Justice 51 (J. Moss (ed.), Carlton, Vic.: Melbourne University Press, 2009).

O'Hara D.P. \& Abelsohn A. Ethical Response to Climate Change, 16(1) Ethics and the Environment 25 (2011).

Shue H. Global Environment and International Inequality, 75(3) International Affairs 531 (1999).

Stern N. The Economics of Climate Change, 98(2) American Economic Review 1 (2008).

Streck C. \& Lin J. Making Markets Work: A Review of CDM Performance and the Need for Reform, 19(2) European Journal of International Law 409 (2008).

Sunstein C.R. Irreversible and Catastrophic: Global Warming, Terrorism, and Other Problems Eleventh Annual Lloyd K. Garrison Lecture on Environmental Law, 23(1) Pace Environmental Law Review 3 (2005).

\section{Information about the author}

Megersa Dugasa Fite (Ambo, Ethiopia) - Lecturer of Law, School of Law, Ambo University (45, Ambo University, Ambo, Ethiopia; e-mail: megiduga153@gmail. com). 